\title{
Developing Student Work Experience Programmes Within the European Higher Education Area Framework: The Role of Social Partners
}

\author{
Dimitrios Skiadas ${ }^{1}$, Sofia Boutsiouki ${ }^{1}$, Vasileios Koniaris ${ }^{1}$, Konstantinos Zafiropoulos $^{1}$ \& Marianthi Karatsiori ${ }^{2}$ \\ ${ }^{1}$ Department of International and European Studies, University of Macedonia, Thessaloniki, Greece \\ ${ }^{2}$ Department of Education and Social Policy, University of Macedonia, Thessaloniki, Greece \\ Correspondence: Sofia Boutsiouki, Department of International and European Studies, University of Macedonia, \\ 156 Egnatia street, 54636 Thessaloniki, Greece.
}

Received: April 13, 2021

doi:10.5539/ies.v14n11p31
Accepted: June 16, $2021 \quad$ Online Published: October 27, 2021

URL: https://doi.org/10.5539/ies.v14n11p31

\begin{abstract}
The aim of establishing the European Higher Education Area (EHEA) marked the development of the Bologna process since its beginning, while it exercised a decisive influence on the content of the higher education policy initiatives undertaken over the years. One of the most important goals of the relevant policy making was to bridge the university-to-labour market gap and to improve the employability of graduates. Such aims require a consistent and multidimensional cooperation between higher education institutions and the social partners, mainly employers, from which significant benefits may derive for all parties involved. As a result, many types of work based learning have been promoted in higher education with the most prominent of them being the student work experience programmes organised by universities in collaboration with enterprises. The paper analyses the guidelines provided by the EHEA framework with regard to the cooperation between universities and the social partners. Also, it discusses the role that has been attributed to (or claimed by) the social partners regarding work experience programmes. The EHEA institutional framework includes provisions for the participation of social partners in the organisation of work placements, which contribute to students' skills development and easier transition to employment.
\end{abstract}

Keywords: university, social partners, work experience programmes, traineeship, European Higher Education Area, European Union

\section{Introduction}

In recent years the university work experience programmes attract much of the attention of academics and policy makers and are included in the reforms that are introduced in the European tertiary education. Under a competency-based approach and with a view to the improvement of the professional qualifications and of the employability of university graduates, these programmes place great importance on the development of the appropriate work-based learning schemes for students to gain the necessary skills and competencies before they enter the labour market. Such goals were included in the Bologna Declaration (1999) and were gradually embedded in the European Higher Education Area (EHEA) framework in the following years; more analytically, the subsequent work groups and the periodic assessment reports attributed great importance to the cooperation between universities and the social partners, mainly employers, in order to bridge the gap between the learning outcomes of the university curricula and the growing skill demand of the labour market.

As the modern work environment was constantly evolving and universities were called upon to accordingly develop their learning activities, the EHEA process broadened its focus on new issues of interest. Although not at the epicenter of the Bologna process since its beginning, work experience programmes have been steadily recognised as an important element of such cooperation. Besides offering students the opportunity to gain valuable skills, competencies and first-hand work experience, these programmes contribute to the establishment of a competitive knowledge-based society and economy in the European Union (EU) (Prague Communiqué, 2001).

This paper is part of the research activity of the "Higher Education Work Experience Programmes" (Hi.Ed.WEP) project, which is supported by the Hellenic Foundation for Research and Innovation under the " $1{ }^{\text {st }}$ Call for HFRI Research Projects to support Faculty Members and Researchers and the procurement of high-cost research 
equipment grant". The research project constitutes an opportunity for a comparative research approach of the current institutional framework and the specific characteristics of traineeship programmes of the Greek higher education institutions; at the same time, it is an opportunity to explore the degree of their harmonisation with the European institutional context. In addition, the research project, by capturing the perceptions of social partners regarding specific work experience initiatives, will use the findings in order to formulate proposals that will enable the more proactive participation of the world of work in a broader context of actions related to the transition of young people to the labour market.

\section{Methodology}

The aim of this paper is to present and analyse the institutional framework of the EHEA process with special emphasis on university work experience programmes (traineeships) and to investigate its direct or indirect provisions regarding the proactive collaboration between universities and the social partners, mainly, employers, trade unions and student associations. The paper bases its analysis on the extensive study of literature presenting theoretical approaches and research that has already been carried out on the subject in question, as well as on the relevant official documents. Its main analysis focuses on the EHEA framework and discusses the role that has been attributed to (or claimed by) the social partners regarding work experience programmes offered by universities to their students. The investigation of the role of social partners in the development of work experience schemes for university students was conducted through the analysis of the Declarations and the official Communiqués that were issued by the European ministers responsible for higher education and articulate the evolution of the Bologna Process and of the EHEA framework. This analysis was supplemented with information from the ten reports drawn up by the Bologna Follow-up Group (BFUG) that assessed the process and advised on the next steps. The promoted guidelines illustrate the EHEA provisions with regard to the involvement of social partners in the design and the implementation of student work experience schemes. The paper comes to a conclusion by formulating specific proposals in order that a closer interaction between universities and social partners improves the quality of student traineeships.

The paper is of particular interest for researchers and policy makers who are interested in integrating new practices in vocational education and training, and in lifelong learning activities. The promotion of such activities can enhance the employability of university graduates and facilitate their transition to the labour market, while it can engage social partners in such initiatives more proactively.

\section{Literature Review}

During recent years various types of work based learning (WBL) activities have been incorporated in national education systems. Work experience programmes, such as apprenticeships and traineeships/internships, appear to be the most prominent types of work based learning. In general, they are defined as workplace learning opportunities that are either part of formal education or take place outside of formal education (even after graduation). During a work experience programme a person spends a period of time in an organisation in order to acquire specific competences required by the labour market (European Commission, 2012b, 2015; European Youth Forum/YFJ, 2011). They are highly valued because they offer students the opportunity to connect the theoretical knowledge of academic studies with the professional action and the acquisition of work experience.

Much of the literature on WBL implementation and quality relates to apprenticeships. There is not a commonly agreed definition of "apprenticeships" in Europe. They are defined differently depending on whether they are based on employment contracts or on contracts signed between the employer, the apprentice and the education provider and whether apprenticeships are remunerated or not (Cedefop, 2014, pp. 25-26). Despite these discrepancies, in general apprenticeships are associated with vocational education and training (VET) and have the following characteristics (European Parliament, 2017):

a. They include learning that alternates between a workplace and an educational or training institution.

b. They are usually considered part of formal education and training.

c. On successful completion, learners acquire a qualification and receive an officially recognised certificate.

The terms "traineeship" and "internship" are often used interchangeably, although many education systems clearly distinguish the one from the other. As regards traineeships/internships, the aforementioned European Parliament study (2017) defines them as a work practice (either as part of a study curriculum or not) including an educational/training component, which is limited in time. Their duration is predominantly short to medium-term (ranging from a few weeks up to six months, and in certain cases lasting one year). Roughly, three broad categories of traineeships/internships can be distinguished:

a. Traineeships/internships that are part of vocational/academic curricula or are part of (mandatory) professional 
training.

b. Traineeships/internships associated with active labour market policies.

c. Traineeships/internships in the open labour market.

Practical training has been embedded into certain, professionally oriented study programmes (e.g. for medical or pharmaceutical studies) in accordance with the EU regulation regarding the recognition of professional qualifications (European Parliament \& Council of the European Union, 2005). Similar provisions are also applied by many countries, which include compulsory work placements in certain types of institutions or in more practice-oriented study programmes. For example, in Denmark, practical training is required at Academies of Professional Higher Education and University Colleges for both first and second cycle students. This is also the case in Austria for Universities of Applied Sciences (Fachhochschule) and in Estonia for professional higher education institutions. Similarly, in Finland, all first cycle Polytechnic degrees include work placements. Practical training is mandatory in Romania in the first cycle and in Portugal for short cycle programmes. In France, gaining professional experience is compulsory for short cycle programmes, as well as for professionally-oriented Licence and Master's programmes. However, beyond the regulated professions, higher education institutions are mostly free to decide whether they include such structured work experiences in their study programmes or not (European Commission, 2015).

There is significant literature supporting the importance of work experience programmes not only for the improvement of the universities' learning strategy (D' Abate, Youndt, \& Wenzel, 2009), but also for the development of a multilevel communication and broader collaboration between different stakeholders related to the tertiary education environment. The cooperative approach is necessary for many first priority issues such as the design of quality academic curricula, the reduction of skill mismatches and the better adaptation of universities to the ongoing dynamic transformation of the international socioeconomic environment (Luo \& Lam, 2019; Reinhard, Wynder, \& Kim, 2020; Thiel \& Hartley, 1997).

The participation in university work experience programmes is considered an important supplement of students' theoretical knowledge foundations. Not only do they develop useful social and professional skills, which would be difficult to acquire in the traditional educational environment, but they also improve their understanding of the working environment, thus enabling themselves to redefine their learning strategy (Martin \& Wilkerson, 2006; Raelin, 2008; Varghese et al., 2012). The experience gained from the work environment helps them to maximise the learning outcomes of their studies and improve their academic performance, while at the same time they enrich their curriculum vitae with new competences; thus, they ensure advantages that will prove valuable for them in the recruitment processes (Anjum, 2020; Gault, Redington, \& Schlager, 2000; Gault, Leach, \& Duey, 2010; Hutchinson, Devins, Hooley, \& Kelsey, 2012; Knouse et al., 1999; Rigsby, Addy, Herring, \& Polledo, 2013; Kolb, 1984; Zimmerman, 1990). Students' participation in work experience programmes offers them additional benefits. They are offered the opportunity to build a useful contact network with various labour market actors, which could strengthen their forward momentum and have a decisive effect on their future career prospects (Dalon \& Pichault, 2008; Knuth, 2008).

Besides students, other groups of stakeholders, such as higher education institutions and businesses, employers and employees, also gain considerable advantages by supporting work experience schemes. Work experience programmes facilitate the development of multilevel communication and creative collaboration among them on common interest issues; they are able to contribute to the design of better academic curricula and to address skill mismatches more efficiently, to develop and disseminate their know-how further, to upgrade their functional competence and enhance their adaptability to the ongoing socioeconomic changes (Blair \& Millea, 2004; Braunstein \& Loken, 2004; CAFCE, 2005; Dalon \& Pichault, 2008; Evans, Hodkinson, Rainbird, \& Unwin, 2006; Evans \& Rainbird, 2002; Gault et al., 2010; Hutchinson et al., 2012; Hymon-Parker \& Smith, 1998; Rigsby et al., 2013; Thiel \& Hartley, 1997; Weible, 2010; Weisz \& Chapman, 2004).

As regards universities, their impact on the development of the region where they are based has already been recognised (Huggins \& Johnston, 2009), thus making their cooperation with local, regional and national stakeholders essential. Under this approach, social partners network with universities to foster cooperation in common interest fields, such as the content of academic curricula, the research funding, the graduates' recruitment and the scholarships for employee training. On the part of universities, they have to design evaluation criteria so as to develop the appropriate networks especially with employers. Student associations can also participate in networking activities, while the institutions' administrative services can contribute to a more effective interaction by providing information to potential employers, by offering guidance and mentoring, and by preparing the recruitment documentation and processes. 
Such cooperation, as evidenced by Chankseliani and Anuar (2019), as well as by Greene, Sapp and Chissom (1990), can contribute to the development of hard and soft skills that allow students to understand the transformations of the world of work and to adapt to them accordingly. By participating in work experience programmes, students face two different environments; the educational environment, which places emphasis on the acquisition of academic, mostly theoretical, knowledge and qualifications, and the work environment, which places emphasis on their practical implementation (Tilman \& Delvaux, 2000). Nevertheless, work experience programmes connect these environments in such a way that they become a single training area, where the student must be able to identify the value of what he/she does (Gagnon, 2008).

In accordance with the above, the student forms a specific identity or representation of the work environment in which he/she will be called upon to operate during his/her adult life in the future. Therefore, the supervisor of a work experience programme must lead the process by being concerned about the coherence of the training (Agulhon, 2000). The supervisor is required to establish a connection between the rationale of learning at the company and that of learning at the university, in order to facilitate the construction of meaning in the work-study life (Fuller \& Unwin, 2009; Sundin, Ogren, \& Boëthius, 2008).

This "optimal crossing" from one environment to the other requires the involvement of various actors or stakeholders (Joaquim, 2007; Merhan, Ronveaux, \& Vanhulle, 2007) and the design of training tools that enhance the acquisition of hard and soft skills by the student (Engeström, Engeström, \& Kärkkäinen, 1995).

Many theoretical approaches involve useful connotations of the value and the implementation of work experience programmes by universities. Seen from a life cycle perspective the theory of adult development has been very successful with the development of adult education since the 1960s. Among the many academics who have adopted this perspective, Jung (1971) was one of the first to propose that human development is part of the process of individuation. Gould (1978) wanted to follow the underground work of the transformation of consciousness and the sense of time, whereas, for Nemiroff and Colarusso (1990), it is the emergence of identity that makes it possible to follow the developing adult. In contrast, for Havighurst (1972), it is the notion of developmental task that represents the central concept of adult development. As we can see, there are many different points of view that aspire to shed original light on one of the constitutive dynamics of human identity.

As regards universities, they experience a continuous pressure to find the right balance between the demand for a curriculum more relevant to labour market needs and the preservation of the academic standards and values. As Little and Brennan (1996) state, "developments directed towards the achievement of the former are frequently perceived to run counter to the preservation of the latter".

The changing approach from marketisation and privatisation strategies to valorisation strategies (Benneworth \& Jongbloed, 2010) is expected to have a significant positive impact on the socioeconomic development and social cohesion. In the context of work experience programmes, training young people to exercise a profession requires special attention in order to align their skills with the challenges that arise due to the complexity and the broad transformation of the labour market.

\section{Work Experience Programmes in the European Policy Making}

The lack of workplace experience and of the related skills and competences contributes to a growing skills gap, and thus to high youth unemployment rates, in Europe (European Commission, 2013b). Experts and policy makers believe that part of the solution lies in WBL. Its activities provide students with real-life work experiences, where they can apply academic and technical skills and develop employability skills and entrepreneurial competence; thus, it facilitates young people's transition from the classroom to the workplace (Farmaki, 2018).

The Declaration on a European Alliance for Apprenticeships (Council of the European Union, 2013) outlined the key messages of European authorities for combating youth unemployment and inactivity, by: providing regulatory and institutional frameworks; integrating apprenticeships in formal education and training; providing a strong, work based, high quality learning and training component; assuring participation of young people with fewer opportunities; and promoting apprenticeship schemes through awareness raising. What is more, by drawing inspiration from a Joint Declaration of the European authorities and the European level social partners (European Alliance for Apprenticeships, 2013), the particular initiative highlighted the importance of the convergence between policy makers and socioeconomic stakeholders. Similarly, the promotion of the need for a Quality Framework for Traineeships (Council of the European Union, 2014) underlined the EU interest in traineeships for young people that are better organised and more effective, and offer official recognition, while a written agreement defines the rights and the responsibilities of each party involved.

According to a report from the European Parliament, there are a number of European-level initiatives, following 
the Bruges Communiqué (2010) and the Riga Conclusions (2015) on VET, which aim to ensure that WBL is of high quality. They emphasised the need for shared responsibility, involving employers and small and medium-sized enterprises (SMEs), and for alignment to the labour market needs, while giving attention to the quality of learning itself. Furthermore, the European Commission (2016b) identified 20 guiding principles for stakeholders involved in WBL. The principles focus on four main themes: involving national governance and social partners; supporting companies, in particular SMEs; making apprenticeships attractive and improving career guidance; and introducing quality assurance. The principles relating to external quality assurance (an accountability mechanism whereby the existence and use of appropriate procedures is verified by an external body), a main topic in this report, include:

a. Providing a clear framework for quality assurance of apprenticeships at the system, provider and company levels, ensuring systematic feedback.

b. Ensuring the content of VET programmes is responsive to changing skill needs in companies and society.

c. Fostering mutual trust and respect through regular cooperation between apprenticeship partners.

d. Ensuring fair, valid and authentic assessment of learning outcomes.

e. Supporting the continuous professional development of in-company trainers and improving their working conditions.

The European authorities also recognise the significance of the connection of education with the economy. In its Communication on a renewed EU agenda for higher education the European Commission (2017) acknowledged that "strengthening the contribution of higher education to innovation requires action across all higher education institutions' activities - education, research and engagement with the wider world. Institutions need to build an outward-looking culture of innovation and entrepreneurship". All forms of WBL contribute to the better understanding of the work environment by students, who aspire their professional integration either as employees or as entrepreneurs.

The European Commission (2003) first referred to the importance of entrepreneurship education in its Green Paper on entrepreneurship in Europe, while the European Parliament and the Council of the European Union (2006) identified the "sense of initiative and entrepreneurship" as one of the eight key competences necessary for all members of a knowledge-based society. The Council of the European Union (2018) reaffirmed the need for countries to nurture "entrepreneurship competence, creativity and the sense of initiative especially among young people". The 2008 Small Business Act for Europe, the Commission Communication on Rethinking Education (European Commission, 2012a), the Entrepreneurship Action Plan 2020 (European Commission, 2013a), and more recently, the New Skills Agenda for Europe (European Commission, 2016a), kept the focus on the promotion of entrepreneurship education and entrepreneurial learning under the spotlight. This has led to a wealth of initiatives across Europe, which enhances the importance of work experience programmes in Higher Education Institutions (HEIs).

Individual countries promote similar objectives. An excellent paradigm comes from the United Kingdom. A report published by the Quality Assurance Agency for Higher Education explains that the goal of enterprise education is to "produce graduates with an awareness, mindset, and capability to generate original ideas in response to identified needs, opportunities, and shortfalls, and the ability to act on them, even if circumstances are changing and ambiguous". Entrepreneurship education, on the other hand, aims to "build upon the enterprising competencies of students who are capable of identifying opportunities and developing ventures, through becoming self-employed, setting up new businesses or developing and growing part of an existing venture. It focuses on the application of enterprising competencies and extends the learning environment into realistic risk environments that may include legal issues, funding issues, start-up, and growth strategies" (QAA/Quality Assurance Agency for Higher Education, 2018).

Although the interaction between HEIs, social partners and students is not a goal that is easy to achieve (Emmenegger \& Seitzl, 2020), over the years the idea for its further development has been established in the EU policy making. A coordinated interaction will allow institutions to be more responsive to employers' needs and employers to better understand the institutional perspective, so as to join forces in order to prepare future graduates with a responsible, inventive and entrepreneurial personality. Higher education institutions, together with governments, government agencies and employers are expected to improve the availability, accessibility and quality of their career and employment-related guidance services for students and alumni. Work placements and on-the-job learning, which should be embedded in study programmes and become part of regular quality reviews, need to be further developed to improve employability of graduates (BFUG, 2010; Louvain-la-Neuve 
Communiqué, 2009).

\section{The EHEA Approach in the Bologna Process}

The Bologna Declaration (1999) signaled the introduction of common reforms in university education that sought the establishment of a European Higher Education Area (EHEA) and the convergence of the member states' higher education systems in key areas of interest (Asderaki, 2008). Since the launch of the Bologna Process member states have made special efforts to build a common operational framework for higher education, in which the interaction between universities and the labour market has been placed very high in the agenda.

The improvement of employability in the European labour marker is placed at the epicenter of attention of the EU agenda and has shaped the relevant policies (Prague Communiqué, 2001; Yerevan Communiqué, 2015). From its early start the Bologna Process recognised that universities should undertake an upgraded role in the future as regards the development of professional skills and the transparency and recognition of qualifications by "specifying the learning outcomes in a way that is meaningful for students, employers and others concerned" (Prague Communiqué, 2001, p. 10).

Although this approach was vague in its initial setting under the framework of an "educational cooperation for the development of stable, peaceful and democratic societies" (Bologna Declaration, 1999), it was later specified under the new approach of lifelong learning and the subsequent pursuit of the European knowledge-based society. The achievement of a knowledge-based society through the promotion of lifelong learning experiences was set to become the basis of the education and economic policy of the EU towards a competitive economy that is able to adapt to the changing international environment effectively (Prague Communiqué, 2001) and higher education systems that are able to address the demand for inclusiveness, innovation and interconnection (Rome Communiqué, 2020).

Although this cooperation was not further analysed by defining the stakeholders, the timeframe and the content, it was deemed to include all stakeholders such as education providers, employers and students' associations, professional chambers and trade unions (Berlin Communiqué, 2003). The emphasis, however, remained on the creation of joint degree programmes, the accreditation and curricula development with the aim to better address skills mismatches in the job market (Berlin Communiqué, 2003). The current setting of dialogue for the Bologna Process was further enhanced with the introduction of the "Bologna Activities at national and institutional levels", where various national and European stakeholders submitted ideas and proposals regarding the Bologna Process. The majority of these stakeholders were social partners, mainly employers, who demonstrated significant interest in participating in these national and European roundtables (Berlin Communiqué, 2003, p. 19). The aforementioned roundtables were also important for HEIs that regarded them as an opportunity to exchange views on issues related to the development of the EHEA in a meaningful and productive way.

Nevertheless, for the next four years the Bologna Process seemed to have reached a stalemate. It was the London Communiqué (2007) that reinforced the debate with new objectives placing emphasis on the reduction of social inequalities and the improvement of the levels of knowledge, skills and competencies in society, as it was indicated within the prevailing framework of lifelong learning. The same aims were also highlighted by the Louvain-la-Neuve Communiqué (2009) and the Bucharest Communiqué (2012).

Although the Bergen (2005) and London (2007) Communiqués did not explicitly referred to the promotion of work experience programmes as a component of lifelong learning, they maintained the focus on the introduction of new types of qualifications and improved curricula, as well as on the enhancement of employability with the cooperation of social partners. Besides the individual national initiatives, the BFUG had to take action to broaden the stakeholders' participation (BFUG, 2004).

Also, the EHEA framework underlines the need for governments to support the organisation of work experience schemes and to ensure subsidies especially for vulnerable groups. Nevertheless, it recognises that for the purposes of flexibility and effectiveness greater responsibility for targeted aspects should be assigned to labour market actors, thus making the involvement of the social partners at local and regional level necessary. Social partners can be involved in many dimensions of university learning activities: design and management of curricula development; consulting universities on new study programmes or on promotion of reforms; participation in universities' decision making bodies and governance; involvement in quality assurance governance bodies and external review teams; collaboration in research projects, skills forecasting and dissemination of national qualification frameworks (NQFs); cooperation with higher education institutions for increased funding and guidance for student or graduate start-ups (Boutsiouki, 2019).

Since the Berlin Communiqué (2005) the focus of the developing framework moved towards new matters that 
contribute to the establishment of lifelong learning culture in the EHEA: development of flexible learning pathways; enhancement of recognition of prior learning; establishment of national qualification frameworks to encompass the wide range of learning paths; achievement of closer cooperation between higher education institutions and external stakeholders (Berlin Communiqué, 2005 p. 5). The concept of lifelong learning was further specified in the Louvain-la-Neuve Communiqué (2009), which stated "lifelong learning implies that qualifications may be obtained through flexible learning paths, including part-time studies, as well as work-based routes" (Louvain-la-Neuve Communiqué, 2009, p. 3).

The Paris Communiqué (2018) maintained the focus on the establishment of synergies between education, research and innovation with regard to better curricula development, which had been introduced by the Quality Framework for Traineeships (Council of the European Union, 2014). The Quality Framework for Traineeships was inspired by the European Quality Charter on Internships and Apprenticeships (European Youth Forum, 2011) and prioritised the cooperation between education providers and social partners, mainly employers, in order to ensure good quality traineeships. The Quality Framework emphasised particular elements: organisation of traineeships; selection of trainees; working conditions; remuneration for trainees by employers; content of traineeships (work duties); evaluation processes for trainees and employers; and interaction and communication between employers and supervising educators.

Evidently, the value of the multilevel cooperation between universities and social partners regarding the organisation of work experience programmes with a positive impact on the personal and professional development of university students -and future graduates- has been established over the years (OECD \& ILO, 2017). This cooperation can take many forms ranging from the mere offering of such opportunities by employers to the participation of social partners in seminars/workshops about skills demand, job search, recruitment processes and entrepreneurship.

\section{Implications to Different Stakeholders}

The EHEA framework is aligned with the existing literature that views work experience programmes as an investment that benefits both the world of work and individual trainees. Businesses mainly focus on the acquisition of job related skills by trainees and prospective employees, which are considered to be a supplementary tool for the company to accomplish its goals. For trade unions, traineeships are seen as the key to the development of a well-trained, highly skilled and adaptable workforce capable of smoother professional integration and greater contribution to competitiveness; nevertheless, they underline that particular attention has to be paid so that such schemes do not become a cheap substitute for regular jobs. Student trainees gain unique experience from the work environment, which accompanies them not only after the completion of the schemes, but also after their graduation.

Specific interventions would optimise the results of higher education work experience programmes: the connection of traineeships with university curricula in combination with the interaction between the labour market needs and the professional orientation of students; the proactive involvement of social partners in the identification of traineeship needs; the appropriate training of the universities' staff, as well as of businesses' mentors, who are responsible for student placements; and finally, the implementation of reliable quality control processes in work experience programmes.

\section{Conclusion}

The paper investigated the provisions of the EHEA framework regarding work experience programmes for university students and focused especially on the role of social partners in their development. The particular form of WBL is strongly associated with the aim to connect students-trainees with the labour market, to facilitate their transition to employment and thus to increase their employability. Different stakeholders can take part in the development of work experience schemes, such as the EU/national and public/private authorities, higher education institutions, employers, employees and students. They are encouraged to contribute their ideas and expertise to the schemes' design and implementation and to find common ground in order to ensure benefits for all parties involved.

The analysis of the EHEA framework shows that the concept of mandatory or optional traineeships has been integrated in the EU higher education policy as part of the initiatives fostering graduates' employability. However, although the important role of social partners in the various dimensions of the school-to-work transition is recognised, the references to their engagement in traineeships remain confined to basic aspects and generalised remarks. The EHEA provisions include mainly indirect references to the social partners' involvement in university work experience schemes, whereas few, yet highly symbolic, explicit remarks highlight particular forms of participation. 
Concerning the personal and professional development of students, as evidenced by Mumford (2002), a collaborative approach to the design of work experience programmes can significantly contribute to the generation and the implementation of new ideas about social organisation and social relations. This vertical cognitive development can be realised through the interaction with social partners, which enable the establishment of multifaceted connections between education and work (Kaklauskas et al., 2018).

\section{Acknowledgments}

This paper is part of the research activity of the research project "Higher Education Work Experience Programmes" (Hi.Ed.WEP), which is supported by the Hellenic Foundation for Research and Innovation under the " $1{ }^{\text {st }}$ Call for HFRI Research Projects to support Faculty Members and Researchers and the procurement of high-cost research equipment grant" (Project Number: 2590). The authors would like to thank the Hellenic Foundation for Research and Innovation for its support and for offering them the opportunity to contribute to the institutional and operational improvement of the traineeship programmes of the Greek universities.

\section{References}

Agulhon, C. (2000). L' alternance: Une notion polymorphe, des enjeux et des pratiques segmentés. Revue Francaise de pedagogie, 131, 55-63. https://doi.org/10.3406/rfp.2000.1044

Anjum, S. (2020). Impact of internship programs on professional and personal development of business students: a case study from Pakistan. Futur Bus J, 6, 2. https://doi.org/10.1186/s43093-019-0007-3

Asderaki, F. St. (2008). Europe and education. The European Higher Education Area. Athens: I. Sideris [in Greek].

Benneworth, P., \& Jongbloed, B. W. (2010). Who matters to universities? A stakeholder perspective on humanities, arts and social sciences valorisation. Higher Education, 59, 567-588. https://doi.org/10.1007/s10734-009-9265-2

Bergen Communiqué. (2005). "The European Higher Education Area-Achieving the goals". Communiqué of the Conference of European Ministers responsible for Higher Education (Bergen, 19-20 May 2005). Retrieved from http://ehea.info/media.ehea.info/file/2005_Bergen/52/0/2005_Bergen_Communique_english_580520. pdf

Berlin Communiqué. (2003). Realising the European Higher Education Area. Communiqué of the Conference of Ministers responsible for Higher Education (Berlin, 19 September 2003). Retrieved from http://www.ehea.info/Upload/document/ministerial_declarations/2003_Berlin_Communique_English_5772 84.pdf

BFUG/Bologna Follow-up Group. (2004). Minutes from the meeting of the Board of the Bologna Follow-up Group (Oslo, 29 January 2004).

BFUG/Bologna Follow-up Group. (2010). Meeting of the Bologna Follow-up Group (Madrid, 18-19 February 2010).

Blair, B. F., \& Millea, M. (2004). Quantifying the benefits of cooperative education. Journal of Cooperative Education, 38(1), 67-72.

Bologna Declaration. (1999). Joint Declaration of the European Ministers of Education (19 June 1999). Retrieved from https://www.ehea.info/media.ehea.info/file/Ministerial_conferences/02/8/1999_Bologna_ Declaration_English_553028.pdf

Boutsiouki, S. (2019). Now you see me, now you don't. Mapping the role of employers within the framework of traineeships for university students. Proceedings of Jean Monnet Chair EduTRIP International Conference "The European Higher Education Area and the European Research Area: The role of the universities and research centers in smart specialization and growth". University of Piraeus (18-19 April 2019).

Braunstein, L. A., \& Loken, M. K. (2004). Benefits of cooperative education for employers. In R. K. Coll, \& C. Eames (Eds.), International handbook for cooperative education: An international perspective of the theory, research and practice of work-integrated learning (pp. 237-245). Boston: World Association for Cooperative Education.

Bruges Communiqué. (2010). "The Bruges Communiqué on enhanced European cooperation in Vocational Education and Training for the period 2011-2020". Communiqué of the European Ministers for Vocational Education and Training, the European Social Partners and the European Commission, meeting in Bruges on 7 December 2010 to review the strategic approach and priorities of the Copenhagen process for 2011-2020. 
Retrieved from https://www.cedefop.europa.eu/files/bruges_en.pdf

Bucharest Communiqué. (2012). "Making the most of our potential: Consolidating the European Higher Education Area". EHEA Ministerial Conference (Bucharest, 26-27 April 2012). Retrieved from http://www.ehea.info/media.ehea.info/file/2012_Bucharest/67/3/Bucharest_Communique_2012_610673.pdf

CAFCE/Canadian Association for Co-operative Education. (2005). Cooperative education manual. A guide to planning and implementing co-operative education programs in post-secondary institutions. Canadian Association for Co-operative Education.

Cedefop. (2014). Terminology of European education and training policy. Second edition. A selection of 130 key terms. Luxembourg: Publications Office of the European Union. https://doi.org/10.2801/15877

Chankseliani, M., \& Anuar, A. M. (2019). Cross-country comparison of engagement in apprenticeships: A conceptual analysis of incentives for individuals and firms. International Journal for Research in Vocational Education and Training, 6(3), 261-283. https://doi.org/10.13152/IJRVET.6.3.4

Council of the European Union. (2013). European Alliance for Apprenticeships. Council Declaration no. 14986/13 (Brussels, 18 October 2013). Retrieved from http://register.consilium.europa.eu/doc/srv?1=EN\&f= ST\%2014986\%202013\%20INIT

Council of the European Union. (2014). Recommendation of 10 March 2014 on a Quality Framework for Traineeships. OJ C 88/1, of 27.03.2014 (pp. 1-4).

Council of the European Union. (2018). Council Recommendation of 22 May 2018 on key competences for lifelong learning. OJ C 189/1, of 4.06.2018.

D'Abate, C. P., Youndt, M. A., \& Wenzel, K. E. (2009). Making the most of an internship: An empirical study of internship satisfaction. Academy of Management Learning \& Education, 8, 527-538. https://doi.org/10.5465/amle.8.4.zqr527

Dalon, G., \& Pichault, F. (2008). Networking: Employers' groups. In B. Gazier, \& F. Bruggeman (Eds.), Restructuring Work and Employment in Europe (chapter 13). Edward Elgar Publishing. https://doi.org/10.4337/9781848442832.00019

Emmenegger, P., \& Seitzl, L. (2020). Social partner involvement in collective skill formation governance. A comparison of Austria, Denmark, Germany, the Netherlands and Switzerland. Transfer: European Review of Labour and Research, 26(1), 27-42. https://doi.org/10.1177/1024258919896897

Engeström, Y., Engeström, R., \& Kärkkäinen, M. (1995). Polycontextuality and boundary crossing in expert cognition: Learning and problem solving in complex work activities. Learning and Instruction, 5(4), 319-336. https://doi.org/10.1016/0959-4752(95)00021-6

European Alliance for Apprenticeships. (2013). Declaration of the European Social Partners, the European Commission and the Lithuanian Presidency of the Council of the European Union (2 July 2013). Retrieved from https://www.consilium.europa.eu/media/31665/joint-declaration_apprentiships.pdf

European Commission - DG Enterprise and Industry. (2003). Green Paper "Entrepreneurship in Europe". $\operatorname{COM}(2003) 27$ final (Brussels, 21.01.2003).

European Commission. (2012a). Communication from the Commission to the European Parliament, the Council, the European Economic and Social Committee and the Committee of the Regions Rethinking Education: Investing in skills for better socio-economic outcomes. COM/2012/0669 final.

European Commission. (2012b). Labour market developments in Europe 2012. European Economy 5|2012. European Commission, Directorate-General for Economic and Financial Affairs. Retrieved from https://ec.europa.eu/economy_finance/publications/european_economy/2012/pdf/ee-2012-5_en.pdf

European Commission. (2013a). Communication from the Commission to the European Parliament, the Council, the European Economic and Social Committee and the Committee of the Regions Entrepreneurship 2020 Action Plan, Reigniting the entrepreneurial spirit in Europe. COM (2012) 795 final (Brussels, 9.01.2013).

European Commission. (2013b). Work-based learning in Europe: practices and policy pointers.

European Commission. (2015). Labour market and wage developments in Europe 2015. https://doi.org/10.2767/786128

European Commission. (2016a). Communication from the Commission to the European Parliament, the Council, the European Economic and Social Committee and the Committee of the Regions A New Skills Agenda for 
Europe, Working together to strengthen human capital, employability and competitiveness $\{$ SWD(2016) 195 final?. COM (2016) 381 final (Brussels, 10.06.2016).

European Commission. (2016b). High-performance apprenticeships \& work-based learning: 20 guiding principles. Luxembourg: Publications Office of the European Union.

European Commission. (2017). Communication from the Commission to the European Parliament, the Council, the European Economic and Social Committee and the Committee of the Regions on a renewed EU agenda for higher education. \{SWD(2017) 164 final\}. COM/2017/0247 final (Brussels, 30.05.2017).

European Parliament \& Council of the European Union. (2005). Directive 2005/36/EC of the European Parliament and of the Council of 7 September 2005 on the recognition of professional qualifications. OJ L 255/22, of 30.09.2005.

European Parliament \& Council of the European Union. (2006). Recommendation of the European Parliament and of the Council of 18 December 2006 on key competences for lifelong learning. OJ L 394/10, of 30.12.2006.

European Parliament. (2017). Skills development and employment: Apprenticeships, internships and volunteering. Directorate General for Internal Policies, Policy Department A: Economic and Scientific Policy. IP/A/EMPL/2016-04, April 2017, PE 602.056.

European Youth Forum (YFJ). (2011). European Quality Charter on Internships and Apprenticeships. Retrieved from https://www.youthforum.org/sites/default/files/publication-pdfs/European\%20Quality\%20Charter.pdf

Evans K., \& Rainbird, H. (2002). The significance of workplace learning for the "learning society". In K. Evans, P. Hodkinson, \& L. Unwin (Eds.), Working to learn: transforming learning in the workplace (pp. 7-28). London: Routledge. https://doi.org/10.4324/9780203417164_chapter_1

Evans, K., Hodkinson, P., Rainbird, H., \& Unwin, L. (2006). Improving workplace learning. London and New York: Routledge. https://doi.org/10.4324/9780203946947

Farmaki, A. (2018). Tourism and hospitality internships: A prologue to career intentions? Journal of Hospitality, Leisure, Sport \& Tourism Education, 23, 50-58. https://doi.org/10.1016/j.jhlste.2018.06.002

Fuller, A., \& Unwin, L. (2009). Change and continuity in apprenticeship: The resilience of a model of learning. Journal of Education and Work, 22(5), 405-416. https://doi.org/10.1080/13639080903454043

Gagnon, S. (2008). Compelling identity: Selves and insecurity in global, corporate management development. Management Learning, 39(4), 375-391. https://doi.org/10.1177/1350507608093710

Gault, J., Leach, E., \& Duey, M. (2010). Effects of business internships on job marketability: the employers' perspective. Education + Training, 52, 76-88. https://doi.org/10.1108/00400911011017690

Gault, J., Redington, J., \& Schlager T. (2000). Undergraduate business internships and career success: Are they related? Journal of Marketing Education, 22, 45-53. https://doi.org/10.1177/0273475300221006

Gould, R. L. (1978). Transformations: Growth and change in adult life. New York: Simon \& Schuster.

Greene, A. C., Sapp, G. L., \& Chissom, B. (1990). Validation of the Stanford-Binet Intelligence Scale: Fourth edition with exceptional black male students. Psychology in the Schools, 27(1), 35-41. https://doi.org/10.1002/1520-6807(199001)27:1<35::aid-pits2310270106>3.0.co;2-q

Havighurst, R. J. (1972). Developmental tasks and education. New York: David McKay.

Hutchinson, J., Devins, D., Hooley, T., \& Kelsey, S. (2012). Developing business, developing careers: how and why employers are supporting the career development of their employees. Report for the UK Commission for Employment and Skills. London: UKCES.

Hymon-Parker, S., \& Smith, C. (1998). Benefits and limitations of internships as viewed by educators and retailers. Journal of Family and Consumer Sciences: From Research to Practice, 90(4), 76-81.

Joaquim, D. (2007). Merhan, F., Ronveaux, C., \& Vanhulle, S. Alternances en formation, 2007. La Lettre de l'AIRDF, 41(2), 31-32. $\quad$ Retrieved from www.persee.fr/doc/airdf_1776-7784_2007_num_41_2_1757_t1_0031_0000_3

Jung, C. G. (1971). Psychological Types: The Collected Works, Volume 6. London: Routledge and Kegan Paul.

Kaklauskas, A., Banaitis, A., Ferreira, F. A. F., Ferreira, J. J., Amaratunga, D., Lepkova, N., Ubartè, I., Banaitienè, N. (2018). An evaluation system for university-industry partnership sustainability: Enhancing 
options for entrepreneurial universities. Sustainability, 10(2), 119. https://doi.org/10.3390/su10010119

Little, B., \& Brennan, J. (1996). A review of work based learning in Higher Education. Department for Education and Employment, Sheffield.

London Communiqué. (2007). "Towards the European Higher Education Area: responding to challenges in a globalised world" (18 May 2007). Retrieved from http://www.ehea.info/Upload/document/ministerial_declarations/2007_London_Communique_English_588 697.pdf

Louvain-la-Neuve Communiqué. (2009). "The Bologna Process 2020-The European Higher Education Area in the new decade". Communique of the Conference of European Ministers responsible for Higher Education (Leuven/Louvain-la-Neuve, 28-29 April 2009). Retrieved from http://www.ehea.info/media.ehea.info/file/2009_Leuven_Louvain-la-Neuve/06/1/Leuven_Louvain-la-Neuv e_Communique_April_2009_595061.pdf

Luo, J. M., \& Lam, C. F. (2019). Qualitative analysis of satisfying and dissatisfying factors in a university-industry cooperation programme. Education Sciences, $9(1), \quad 56$. https://doi.org/10.3390/educsci9010056

Martin, D. R., \& Wilkerson, J. E. (2006). An examination of the impact of accounting internships on student attitudes and perceptions. The Accounting Educators' Journal, XVI, 129-138.

Merhan, F., Ronveaux, C., \& Vanhulle, S. (Eds.). (2007). Alternances en formation. Bruxelles: De Boeck. https://doi.org/10.3917/dbu.merha.2007.01

Mumford, M. D. (2002). Social innovation: ten cases from Benjamin Franklin. Creativity Research Journal, 14, 253-266. https://doi.org/10.1207/s15326934crj1402_11

Nemiroff, R. A., \& Colarusso, C. A. (Eds.). (1990). New dimensions in adult development. Basic Books/Hachette Book Group.

OECD \& ILO. (2017). Engaging employers in apprenticeship opportunities: Making it happen locally. Paris, France: OECD Publishing. https://doi.org/10.1787/9789264266681-en

Paris Communiqué. (2018). "Empowering Europe's Youth" (Paris, 25 May 2018). Retrieved from http://www.ehea.info/media.ehea.info/file/2018_Paris/77/1/EHEAParis2018_Communique_final_952771.p df

Prague Communiqué. (2001). "Towards the European Higher Education Area". Communiqué of the meeting of European Ministers in charge of Higher Education (Prague, 19 May 2001). Retrieved from http://www.ehea.info/media.ehea.info/file/2001_Prague/44/2/2001_Prague_Communique_English_553442. pdf

QAA (Quality Assurance Agency for Higher Education). (2018). Enterprise and Entrepreneurship Education: Guidance for UK Higher Education providers. The Quality Assurance Agency for Higher Education.

Raelin, A. (2006). Does action learning promote collaborative leadership? Academy of Management Learning and Education, 5(2), 152-168. https://doi.org/10.5465/amle.2006.21253780

Reinhard, K., Wynder, M., \& Kim, W.S. (2020). Developing best practice for cooperative and work-integrated education: Lessons from Germany, Australia and South Korea. International Journal of Work-Integrated Learning, 21(2), 177-191.

Riga Conclusions. (2015). Conclusions of Ministers in charge of vocational education and training (VET), of 22 June 2015, on a set of medium-term deliverables in the field of VET for the period 2015-2020, as a result of the review of short-term deliverables defined in the 2010 Bruges Communiqué. Retrieved from https://www.refernet.de/dokumente/pdf/2015-riga-conclusions_en.pdf

Rigsby, J. T., Addy, N., Herring, C., \& Polledo, D. (2013). An examination of internships and job opportunities. The Journal of Applied Business Research, 29(4), 1131-1144. https://doi.org/10.19030/jabr.v29i4.7921

Rome Communiqué. (2020). Rome Ministerial Communiqué (19 November 2020). Retrieved from http://www.ehea.info/Upload/Rome_Ministerial_Communique.pdf

Sundin, E., Ogren, M. L., \& Boëthius, S. (2008). Supervisor trainees' and their supervisors' perceptions of attainment of knowledge and skills: An empirical evaluation of a psychotherapy supervisor training programme. The British Journal of Clinical Psychology/the British Psychological Society, 47, 381-96. 
https://doi.org/10.1348/014466508x304414

Thiel, G.R., \& Hartley, N.T. (1997). Cooperative education: A natural synergy between business and academia.

S.A.M. Advanced Management Journal, 62(3), 19-24.

Tilman, F., \& Delvaux, E. (2000). Manuel de la formation en alternance. Chronique sociale.

Varghese, M. E., Parker, L. C., Adedokun, O., Shively, M., Burgess, W., Childress, A., \& Bessenbacher, A. (2012). Experiential internships: Understanding the process of student learning in small business internships. Industry and Higher Education, 26(5), 357-367. https://doi.org/10.5367/ihe.2012.0114

Weible, R. (2010). Are universities reaping the available benefits internship programs offer? Journal of Education for Business, 85(2), 59-63. https://doi.org/10.1080/08832320903252397

Weisz, M., \& Chapman, R. (2004). Benefits of cooperative education for educational institutions. In R.K. Coll \& C. Eames (Eds.), International handbook for cooperative education: an international perspective of the theory, research and practice of work-integrated learning (pp. 247-258). Boston: World Association for Cooperative Education.

Yerevan Communiqué. (2015). Communiqué of the Ministerial Conference (Yerevan, 14-15 May 2015). Retrieved from http://www.ehea.info/Upload/document/ministerial_declarations/YerevanCommuniqueFinal _613707.pdf

\section{Copyrights}

Copyright for this article is retained by the author(s), with first publication rights granted to the journal.

This is an open-access article distributed under the terms and conditions of the Creative Commons Attribution license (http://creativecommons.org/licenses/by/4.0/). 